\title{
DAMPAK DISINTERMEDIASI KEGIATAN BANK TERHADAP EFEKTIVITAS KEBIJAKAN MONETER
}

\section{Y. Santoso Wibowo dan Gunawan *)}

Selama dekade terakhir, perkembangan perusahaan pembiayaan dan lembaga keuangan lainnya termasuk pasar modal telah berkembang pesat. Perkembangan pasar modal yang ditandai dengan meningkatnya emiten di bursa efek, nilai kapitalisasi pasar, nilai perdagangan di pasar sekunder, serta lembaga penunjang pasar modal seperti perusahaan sekuritas, broker dan perusahaan penjamin emisi penjualan saham tersebut berdampak pada berkurangnya peran perbankan sebagai lembaga perantara (disintermediasi) yang pada gilirannya akan berdampak pada efektivitas kebijakan moneter. Untuk mengetahui dampak disintermediasi tersebut dilakukan pengujian terhadap terjadinya proses disintermediasi serta pengaruhnya terhadap efektivitas kebijakan moneter, dan sebagai perbandingan dikemukakan juga proses disintermediasi yang terjadi di Spanyol, Perancis dan Korea Selatan.

Hasil penelitian menunjukkan bahwa dalam periode 1990-1997 pangsa kapitalisasi pasar dibandingkan pangsa kredit meningkat dari $1 / 9$ menjadi $2 / 3$, menunjukkan semakin besarnya peran pasar modal. Prosed disintermediasi telah terjadi terutama pada periode 1995-1997, khususnya untuk penanaman dana berjangka panjang yang ditandai dengan mengecilnya selisih antara pendapatan di pasar perbankan dengan pendapatan di pasar modal. Disintermediasi tersebut masih relatif lemah karena pertumbuhan pasar modal masih searah dengan pertumbuhan kredit, dan kedua pasar belum saling meniadakan. Proses disintermediasi tersebut belum mengganggu efektivitas kebijakan moneter karena perubahan kredit dan kapitalisasi pasar hanya merupakan komponen kecil dari residual M2, meskipun pertumbuhan kapitalisasi pasar lebih berpengaruh terhadap efektivitas kebijakan moneter dibandingkan dengan pertumbuhan kredit. Mengingat korelasi antara suku bunga deposito dengan pertumbuhan IHSG cukup dekat dan signifikan, maka untuk mencegah proses dis-intermediasi di masa mendatang perlu diupayakan suku bunga yang stabil dalam jangka panjang.

*) Y. Santoso Wibowo : Peneliti Ekonomi, Bagian Studi Ekonomi dan Lembaga Internasional, UREM, BI, Email: santoso@bi.go.id

Gunawan : Ass. Peneliti Ekonomi, Bagian Studi Struktur dan Perkembangan Pasar Keuangan, UREM, BI

Penulis mengucapkan terimakasih untuk diskusi dan komentar dari Heryanti Hermanto, Peneliti Ekonomi Yunior, Bagian Studi Sektor Riil, UREM-BI, dan bantuan dalam proses penelitian kepada Erwin Gunawan Hutapea, Asisten Peneliti Ekonomi, Bagian Studi Struktur dan Perkembangan Pasar Keuangan, UREM-BI 


\section{Pendahuluan}

elama dekade 1990-an, pasar modal, perusahaan pembiayaan, dan lembaga keuangan lainnya menunjukkan perkembangan pesat. Perkembangan di pasar modal ditandai dengan munculnya perusahaan reksadana, semakin tingginya frekuensi kegiatan investor, semakin besarnya nilai kapitalisasi pasar, meningkatnya jumlah emiten dan lembaga penunjang pasar modal seperti perusahaan sekuritas, broker dan perusahaan penjamin. Perkembangan tersebut patut diperhitungkan karena berpotensi untuk menjadi pesaing bank dalam menjalankan fungsinya sebagai lembaga perantara keuangan dan mempercepat terjadinya proses disintermediasi kegiatan bank di Indonesia.

Proses disintermediasi kegiatan bank secara umum timbul karena pihak peminjam dan yang meminjamkan dana bertemu langsung tanpa melalui lembaga perantara. ${ }^{1}$ Proses ini terjadi baik karena pasar sudah mempertemukan kedua pihak secara langsung, maupun ada lembaga non-bank yang menggantikan peran bank sebagai perantara. Proses disintermediasi tersebut jarang terjadi secara permanen, dan pada umumnya hanya bersifat temporer sebelum pasar menemukan keseimbangan baru atau hanya terjadi pada segmen tertentu dimana pada segmen tersebut pasar terintegrasi.

Perkembangan di sektor keuangan pada gilirannya akan berpengaruh terhadap kebijakan moneter secara keseluruhan, terlebih lagi karena sejauh ini kebijakan moneter di Indonesia hanya dapat mempengaruhi langsung kepada sektor perbankan, maka peran sektor keuangan di luar perbankan yang semakin besar kemungkinan akan berdampak pada berkurangnya efektivitas kebijakan moneter. Melihat perkembangan tersebut, menarik untuk diamati beberapa fenomena yang terjadi dalam penanaman dan permintaan dana di pasar modal dan perbankan beserta perubahannya selama beberapa tahun terakhir, serta pengaruh perubahan tersebut terhadap efektivitas kebijakan moneter. Dengan demikian diharapkan dapat diperoleh gambaran apakah di Indonesia dewasa ini sudah terjadi proses disintermediasi kegiatan bank, serta bagaimana dan seberapa besar pengaruhnya terhadap efektivitas kebijakan moneter.

\section{Metode Analisis Proses Disintermediasi}

Sejauh ini belum ada ukuran yang baku untuk mengukur disintermediasi yang terjadi di sektor keuangan, di mana peran bank dalam menghimpun dan menyalurkan dana seolaholah berkurang karena adanya lembaga lain yanng masuk dalam persaingan. Untuk itu sebagai pendekatan terhadap proses disintermediasi, digunakan konsep "integrasi" di pasar keuangan dimana dana dapat berpindah dari satu pasar ke pasar yang lain dengan mudah tanpa batasan. Dengan menggunakan pendekatan keseimbangan dan integrasi di pasar keuangan tersebut, maka pembahasan di sini lebih diarahkan pada kemungkinan terjadinya disintermediasi atau lebih tepatnya konsolidasi pasar, dengan menggunakan metode analisis :

1) perbedaan harga/selisih dari pendapatan di pasar modal dengan suku bunga

2) perbandingan pangsa pasar

3) perbandingan pertumbuhan kuantitas

4) ARMA $(1,2)$ untuk menguji efektivitas kebijakan moneter 
Analisis akan difokuskan pada analisis grafik dan perhitungan kuantitatif dengan ekonometrik sederhana (meliputi : statistik deskriptif, korelasi, elastisitas harga serta tes Granger) dan pendekatan ARMA untuk meneliti residual M2 sebagai penyimpangan M2 dari target yang hendak dicapai. Pergeşeran dana dari perbankan ke pasar modal atau sebaliknya dianalisis dengan menggunakan pendekatan selisih antara penanaman dana dalam bentuk deposito dengan penanaman dana di pasar modal. Keuntungan yang diperoleh dari pasar modal $\left(R_{m}\right)$ atau equity yield diukur dengan menjumlahkan keuntungan yang diperoleh dari perubahan harga saham (capital gain) dengan pendapatan dividen (divident yield).

$\begin{aligned} \begin{array}{l}\text { Pendapatan di pasar }\left(R_{m}\right) \\ \text { (market return) }\end{array} & =\frac{\Delta I H S G}{I_{H S G}}+\frac{D_{1}}{I_{H S G}} \\ & =\frac{I^{I H S G}}{I_{H S G}}-1+\frac{D_{1}}{I H S G_{0}}\end{aligned}$

Mengingat dividen nilainya sangat kecil maka sebagai indikator keuntungan dari pasar modal digunakan persentase perubahan bulanan IHSG, berdasarkan berapa bulan tenggang waktu (lag) yang dikehendaki. ${ }^{2}$

Pasar modal dan perbankan dikatakan bersaing ketat apabila rata-rata selisih suku bunga diantara kedua pasar tersebut mengecil atau secara statistik sama dengan nol $\left(R_{\text {ihs }}\right.$ $-R_{\text {dep }}=0$ ), dalam kondisi ini akan terjadi proses substitusi atas penawaran dana dan kedua pasar tersebut terintegrasi. ${ }^{3}$ Apabila perhitungan pendapatan di pasar modal secara signifikan lebih tinggi/rendah dari pendapatan bank, dimana $\left(R_{\text {ihsg }}-R_{\text {dep }}\right)>0$ atau $\left(R_{\text {ihsg }}-\right.$ $\mathbf{R}_{\text {dep }}<0$, maka pasar tidak terintegrasi, melainkan terpisah.

Sementara itu, pergeseran pangsa pasar akan terjadi jika $G_{\text {mcap }}>G_{\text {crd }}$ atau $G_{\text {mcap }}>G_{\text {dep }}$ yang berarti bahwa pasar modal semakin berperan. Apabila dalam jangka panjang secara konsisten $\left(R_{\text {ihsg }}-R_{\text {dep }}\right)<0$, rata-rata $\left(R_{\text {ihsg }}-R_{\text {dep }}\right)_{t}=$ rata-rata $\left(R_{\text {ihsg }}-R_{\text {dep }}\right)_{t+k}$ terjadi bersamasama dengan $G_{\text {mcap }}>0, G_{\text {crd }}<0$ maka telah terjadi disintermediasi dimana perbankan kehilangan pangsanya, atau dengan kata lain pada kondisi ini pasar modal merupakan substitusi dari produk kredit atau deposito perbankan. ${ }^{4}$

Jika karakteristik masing-masing segmen pasar untuk pasar modal dan perbankan berbeda, dimana pertumbuhan kapitalisasi saham lebih besar dari pertumbuhan kredit $\left(G_{\text {mcap }}>G_{\text {crd }}>0\right)$ maka hal tersebut menunjukkan adanya perbedaan pertumbuhan di kedua pasar, sehingga kedua produk bukan merupakan substitusi bagi pihak yang membutuhkan dana (deficit spending unit). Sebaliknya bila fenomena di atas terjadi pada saat karakteristik

2 Pada umumnya investor yang menanamkan dananya dalam jangka pendek di pasar modal dengan perubahan IHSG sebagai pertimbangan utama. Tes statistik dari rata-rata selisih antara IHSG dengan suku bunga deposito dianggap merupakan estimasi yang paling mewakili kondisi pasar yang terintegrasi

3 Ceteris paribus bila rata-rata perbedaan selisih suku bunga diantara kedua pasar mengecil (secara statstik $=0$ ) akan memacu terjadinya proses disintermediasi di sektor perbankan sehingga dana yang semula melalui bank akan berpindah secara fleksibel menjadi tidak melalui bank.

$\begin{aligned} & 4 \text { Keterangan notasi : } \mathbf{R}_{\text {issg }}=\text { pendapatan (return) di IHSG } \\ & \mathbf{R}_{\text {dep }}=\text { pendapatan (return) suku bunga deposito } \\ & \mathrm{G}_{\text {mcep }}=\text { pertumbuhan kapitalisasi pasar } \\ & \mathrm{G}_{\mathrm{dep}}=\text { pertumbuhan deposito } \\ & \mathrm{G}_{\text {erd }}=\text { pertumbuhan kredit }\end{aligned}$


kedua segmen pasar hampir sama, tetapi kriteria kebutuhan dana atau tujuan investasi antara pihak yang memperoleh dana dari pasar modal dengan yang memperolehnya dari ${ }^{\circ}$ bank berbeda, maka dapat dikatakan telah terjadi disintermediasi dengan tergesernya produk perbankan oleh produk pasar,modal.

Selanjutnya, dalam menganalisis dampak disintermediasi terhadap efektivitas kebijakan moneter, digunakan M2 sebagai indikator efektif atau tidaknya kebijakan moneter. Pemilihan M2 sebagai indikator dengan pertimbangan bahwa M2 dianggap telah mencerminkan perputaran uang dalam kegiatan ekonomi masyarakat dan perbankan. Efektivitas kebijakan moneter tersebut diindikasikan dengan kecilnya gejolak jumlah uang beredar (M2), artinya realisasi jumlah uang beredar mendekati target yang ditetapkan untuk menunjang stabilitas perekonomian. ${ }^{5}$

Berdasarkan uraian di atas, maka upaya meningkatkan efektivitas kebijakan moneter dapat dinyatakan sebagai meminimumkan residual |e|, dimana semakin kecil |e | maka kebijakan moneter semakin efektif.

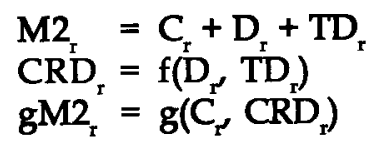

Dengan asumsi $\mathrm{M}_{\mathrm{r}}=\mathrm{Md}$

$$
\begin{aligned}
& M 2_{r}=\text { realisasi uang beredar } \\
& \mathrm{CRD}_{\mathrm{r}}=\text { realisasi kredit } \\
& \mathrm{C}_{\mathrm{r}}=\text { uang kartal, } \\
& \mathrm{D}_{\mathrm{r}}=\text { uang giral } \\
& \mathrm{TD}_{\mathrm{r}}=\text { deposito berjangka } \\
& \mathrm{M} 2_{\mathrm{p}}=\text { target uang beredar } \\
& \mathrm{e}=\text { residual }
\end{aligned}
$$
maka :

Dengan asumsi target uang beredar M2 mengikuti penyesuaian dari tahun sebelumnya,

$$
\begin{aligned}
& \mathrm{M} 2_{\mathrm{p}^{(t)}}=\mathrm{M} 2_{\mathrm{p}(\mathrm{t}-1)}+\mathrm{c}\left(\mathrm{M} 2_{\mathrm{rt}-1}-\mathrm{M} 2_{\mathrm{pt}-1}\right) \\
& \mathrm{M} 2_{\mathrm{t}}=(1-\mathrm{c}) \mathrm{M} 2_{\mathrm{p}(\mathrm{t}-1)}+\mathrm{cM} 2_{\mathrm{r}(\mathrm{t}-1)}+\mathrm{e}
\end{aligned}
$$

Model ini dapat didekati dengan:

$$
\mathrm{M2}=\mathrm{AR}(\mathrm{p})+\mathrm{MA}(\mathbf{q})+\mathrm{e}
$$

Modifikasi ARMA(1,2) digunakan bila penyesuaiannya berselang-seling dan ARMA (1,1) bila penyesuaiannya berkelanjutan. Jadi |e | merupakan residual dari series M2 dengan model ARMA kombinasi $(p, q)$ yang dipilih paling sesuai. Dengan pendekatan ini dapat dikatakan bahwa kebijakan moneter tersebut efektif bila nilai rata-rata dan standar deviasinya semakin mengecil. Pengujian residual M2 terhadap perubahan kredit dan kapitalisasi pasar, dilakukan dengan persamaan berikut:

$$
|\mathrm{e}|=\mathrm{g}\left(\mathrm{MKap}_{\mathrm{r}}, \mathrm{CRD}_{\mathrm{r}}\right)
$$


Apabila hasil pengujian terhadap kedua variabel tersebut tidak signifikan, maka kemungkinan besar residual dipengaruhi faktor-faktor lain di luar kapitalisasi pasar dan kredit. Jika kondisi tersebut terpenuhi, berarti ketidak-efektifan kebijakan moneter kemungkinan dapat dijelaskan oleh fakta terjadinya disintermediasi sebagai berikut :

\section{$|\mathrm{e}|=\mathrm{f}$ (selisih pendapatan di dua pasar)}

Disintermediasi tidak berdampak terhadap efektifitas kebijakan moneter bila nilai rata-rata dan standar deviasi selisih pendapatan serta residual M2 terbukti sama-sama mengecil sejalan dengan terpenuhinya kondisi disintermediasi (selisih antara pendapatan di pasar modal dan perbankan mendekati nol).

\section{Perkembangan Pasar Modal Dan Perbankan Di Indonesia}

Pesatnya perkembangan pasar modal dan perbankan mulai terlihat jelas sejak periode '90-an, dimana kredit dan deposito tumbuh rata-rata $1,8 \%$ setiap bulannya atau $21 \%$ per tahun (Grafik 3.1). Pertumbuhan kredit tersebut terlihat melambat pada periode 1991-93 antara lain dipengaruhi oleh Pakfeb-91 tentang prudential banking, mendorong sektor usaha untuk mencari alternatif pembiayaan lain, salah satunya adalah melalui pasar modal. Disamping itu, pergeseran orientasi pihak yang membutuhkan dana dari perbankan ke pasar modal juga berperan dalam mendorong peningkatan nilai kapitalisasi pasar sehingga pada pertengahan tahun 1997 telah mendekati jumlah outstanding kredit. Kebijakan pemerintah di sektor keuangan pada bulan Mei 1993 (Pakmei-93), kembali memacu kegiatan bank serta pasar modal sehingga perkembangan kredit dan kapitalisasi saham mulai meningkat lagi sejak bulan Mei 1993.

Meskipun sama-sama mengalami pertumbuhan pesat, namun pertumbuhan kapitalisasi pasar nampak lebih besar dan berfluktuasi dibandingkan dengan pertumbuhan kredit (Grafik 3.2). Naik turunnya pertumbuhan kapitalisasi pasar tersebut tidak dapat dihindari karena fluktuasi tersebut sangat dipengaruhi oleh fluktuasi harga saham (IHSG). IHSG yang bergerak sangat fluktuatif merupakan cerminan perubahan ekspektasi pelaku pasar dalam jangka pendek. Semakin besarnya peran pasar modal ditunjukkan oleg besarnya rata-rata pertumbuhan kapitalisasi pasar beberapa tahun terakhir, yang berkisar antara $1,5 \%-2 \%$ dengan standar deviasi yang semakin mengecil.

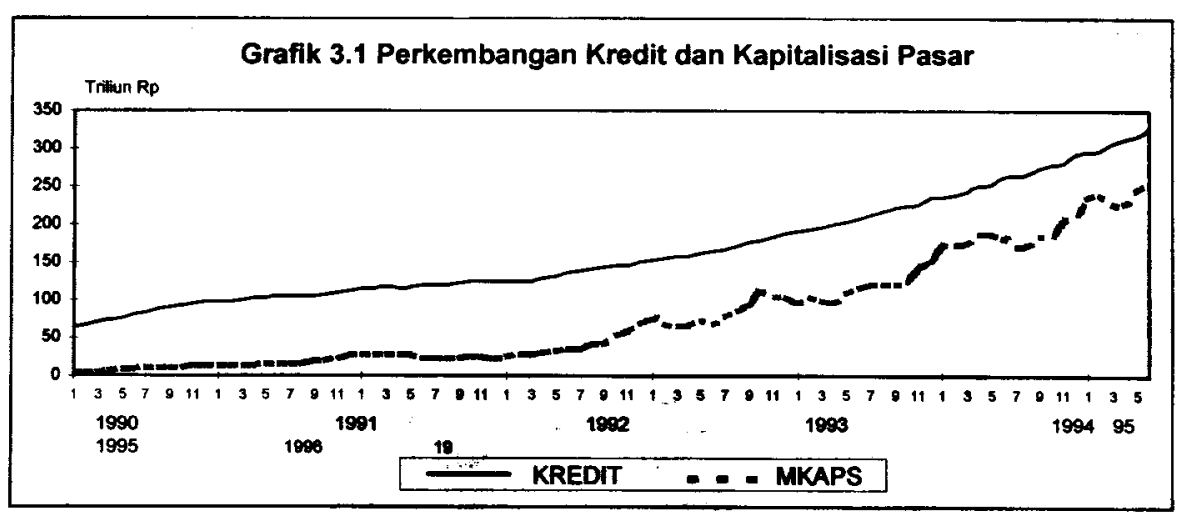




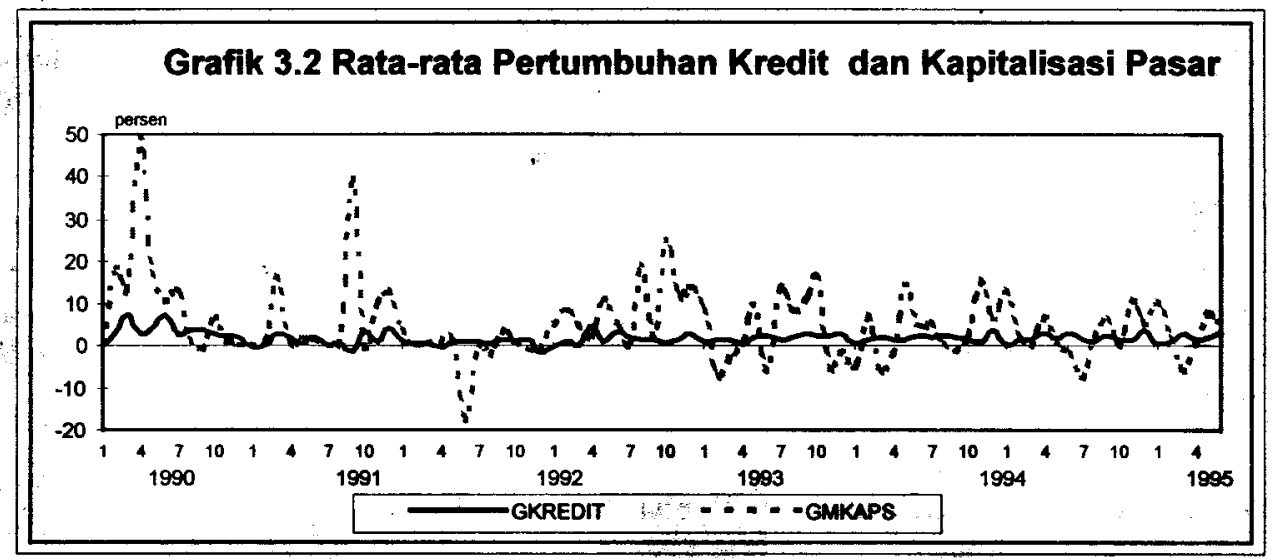

Pertumbuhan IHSG yang menarik pada awal pertumbuhan pasar modal telah mendorong pemilik dana untuk mengalihkan penanaman dalam bentuk deposito kepada saham dengan harapan untuk memperoleh keuntungan dari perubahan harga saham (capital gain) yang lebih besar, walaupun prosedur transaksi di pasar modal lebih rumit serta risiko atas fluktuasi harga yang lebih besar (Grafik 3.3). Ditinjau dari sisi pihak yang membutuhkan dana, pasar modal lebih diminati terutama oleh pihak yang membutuhkan dana dalam jumlah besar dengan biaya yang murah, sebaliknya, pengusaha kecil lebih cenderung memanfaatkan kredit bank karena aksesnya lebih memungkinkan walaupun beban suku bunga yang harus dibayar lebih tinggi.

Selanjutnya, apabila ditinjau dari segi penawaran dan permintaan dana, tedapat perbedaan karakteristrik antara perbankan dengan pasar modal. Penawaran dan permintaan dana di perbankan relatif hanya dipengaruhi oleh suku bunga yang relatif lebih stabil (Grafik 3.4), sedangkan di pasar modal terdapat banyak faktor jangka pendek yang berpengaruh terhadap para pasar modal, diantaranya termasuk kebijakan pemerintah. Dengan asumsi kondisi perekonomian tetap stabil serta kebijakan pemerintah cukup kondusif, maka diperkirakan perkembangan pasar modal akan menyamai atau bahkan melampaui perkembangan perbankan.

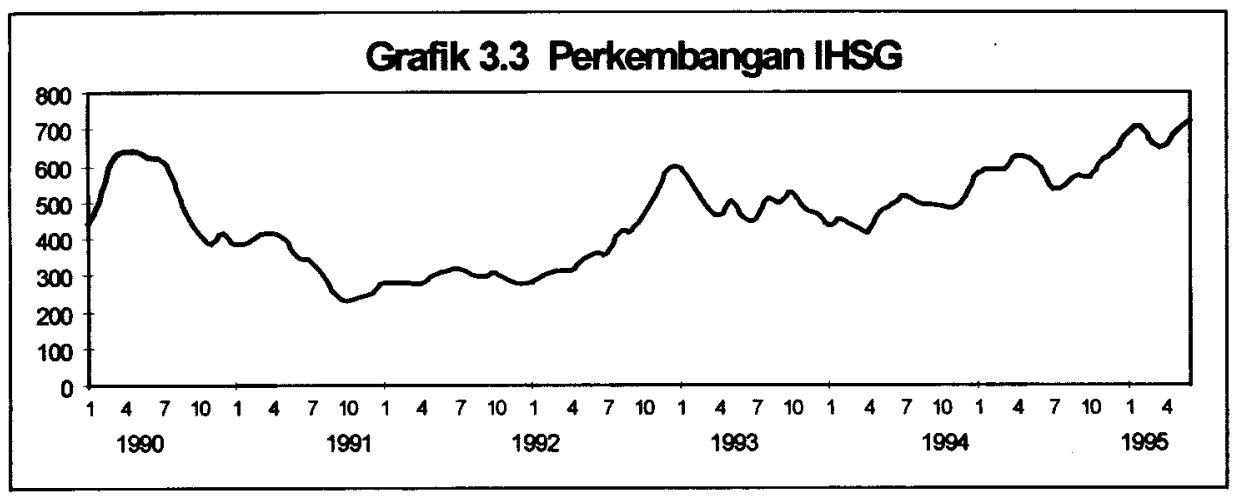




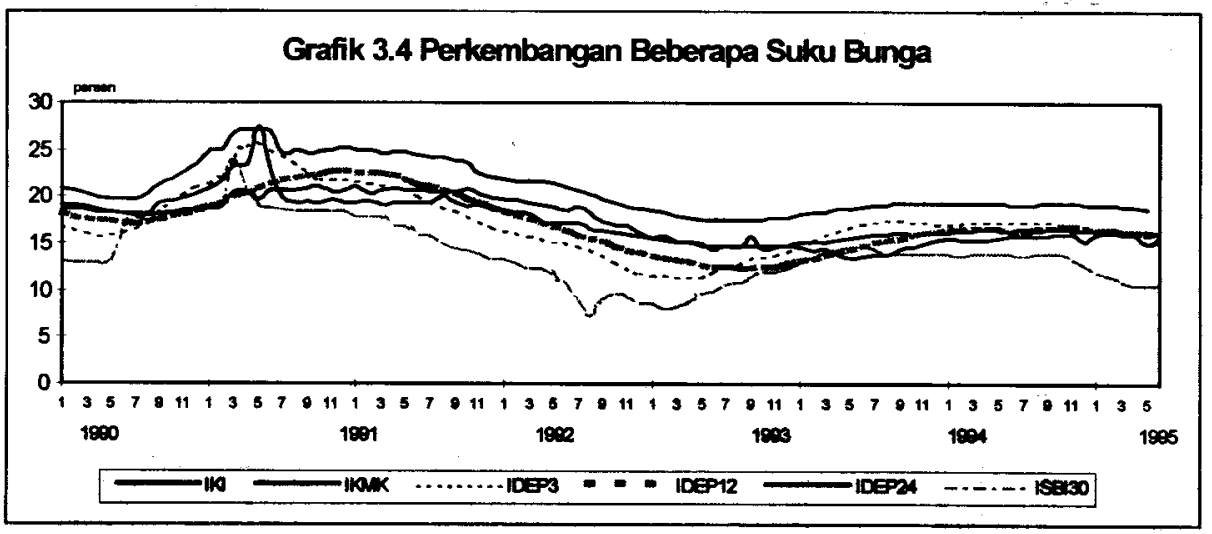

\section{Proses Disintermediasi Di Indonesia}

\section{Analisis Disintermediasi Kegiatan Bank}

Terdapat beberapa fenomena yang menarik untuk diamati dalam perekonomian Indonesia berkaitan dengan proses perkembangan perbankan dan pasar modal, diantaranya adalah (i) terintegrasinya beberapa pasar modal dan perbankan, dimana pelaku pasar dapat berpindah dari satu pasar ke pasar yang lain secara fleksibel sehingga terjadi proses substitusi, dan (ii) terjadinya hubungan saling melengkapi (komplementer) antara satu pasar dengan pasar yang lain. Berangkat dari fenomena-fenomena tersebut, proses disintermediasi di Indonesia dapat diamati dari dua sisi, yaitu : (i) sisi kuantitas, dimana pada kurun waktu 19901997 pertumbuhan kapitalisasi saham yang hampir mencapai tiga kali pertumbuhan outstanding kredit maupun deposito, dan rasio perbandingan pangsa pasar modal terhadap perbankan yang semakin besar, menunjukkan bahwa pasar modal semakin berperan dibandingkan perbankan, (ii) Sisi harga (pendapatan) dengan memperhatikan perbedaan antara pertumbuhan IHSG dengan suku bunga deposito sebagai indikator penanaman dana.

Sejalan dengan semakin majunya sektor keuangan, maka kebutuhan masyarakat akan dana dapat dipenuhi selain dari perbankan dalam bentuk kredit juga dapat dipenuhi melalui pasar modal atau dengan menerbitkan obligasi serta sumber-sumber lainnya. ${ }^{6}$ Proses disintermediasi di Indonesia secara grafis dapat dilihat dengan meningkatnya peran pasar modal yang semakin besar dibandingkan perbankan. Meningkatnya peran pasar modal tersebut terlihat dari menurunnya pangsa kredit terhadap pasar modal dari 9:1 pada tahun 1990 menjadi sekitar 6:4 pada bulan Juni 1997.

Meningkatnya peran pasar modal tersebut diikuti dengan perkembangan IHSG yang semakin meningkat, dengan fluktuasi yang tajam terutama untuk pertumbuhan IHSG pada jangka pendek (1 dan 3 bulan), namun untuk yang berjangka 12 dan 24 bulan fluktuasi tersebut nampak lebih kecil dengan rata-rata gejolak penurunan IHSG lebih kecil dibandingkan kenaikannya (Grafik 4.2). 

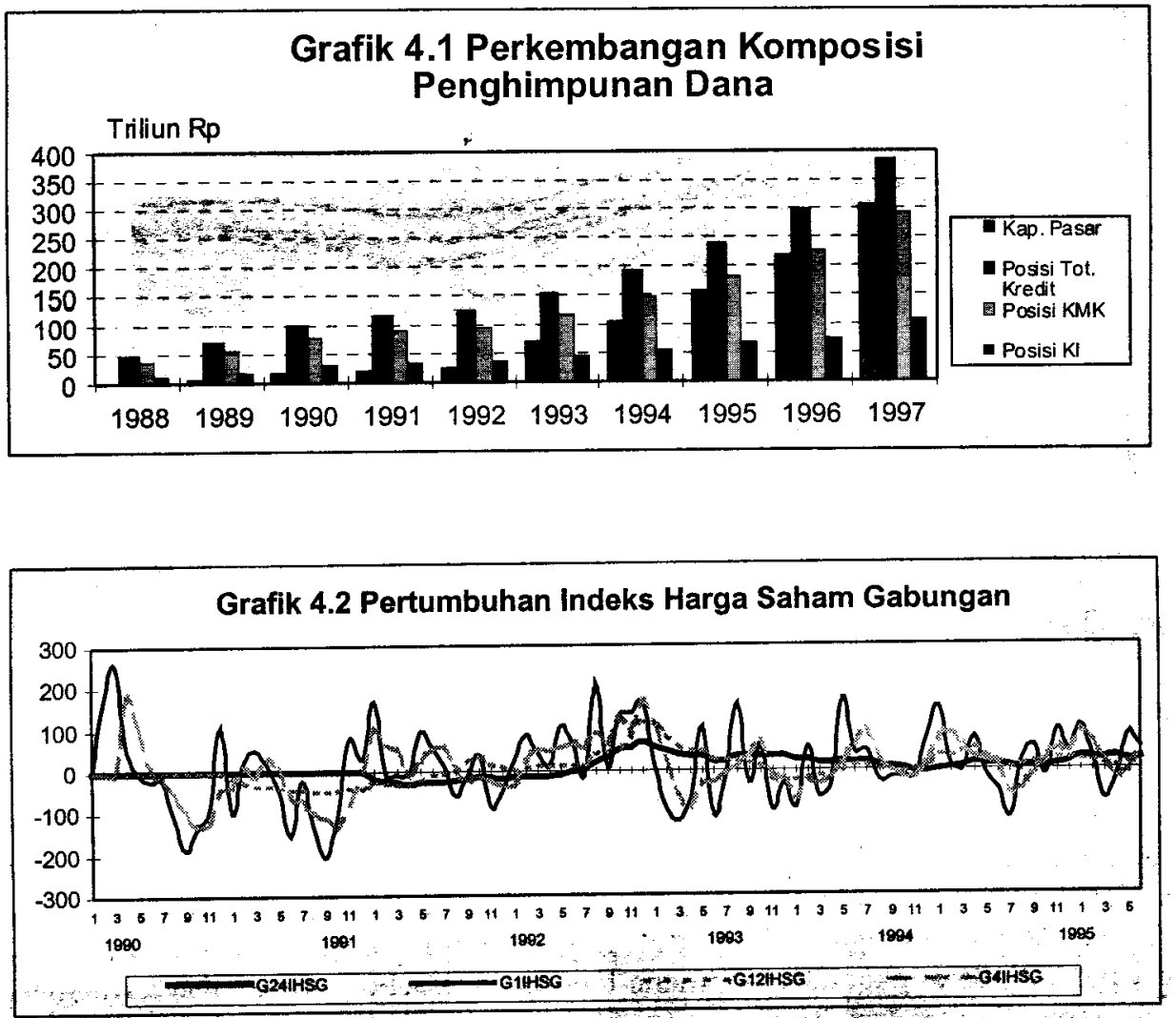

Jika di pasar modal ditandai dengan gejolak IHSG, suku bunga penanaman dana di perbankan justru terlihat semakin stabil dan mengarah pada satu titik untuk hampir semua jangka waktu penanaman, dimana suku bunga deposito 12 bulan terlihat relatif paling stabil, sedangkan untuk deposito 24 bulan terdapat fluktuasi bulanan yang cukup tajam. Fluktuasi bulanan yang cukup tajam untuk deposito 24 bulan tersebut kemungkinan karena adanya ekspektasi jangka panjang dari pemilik dana (Grafik 4.3).

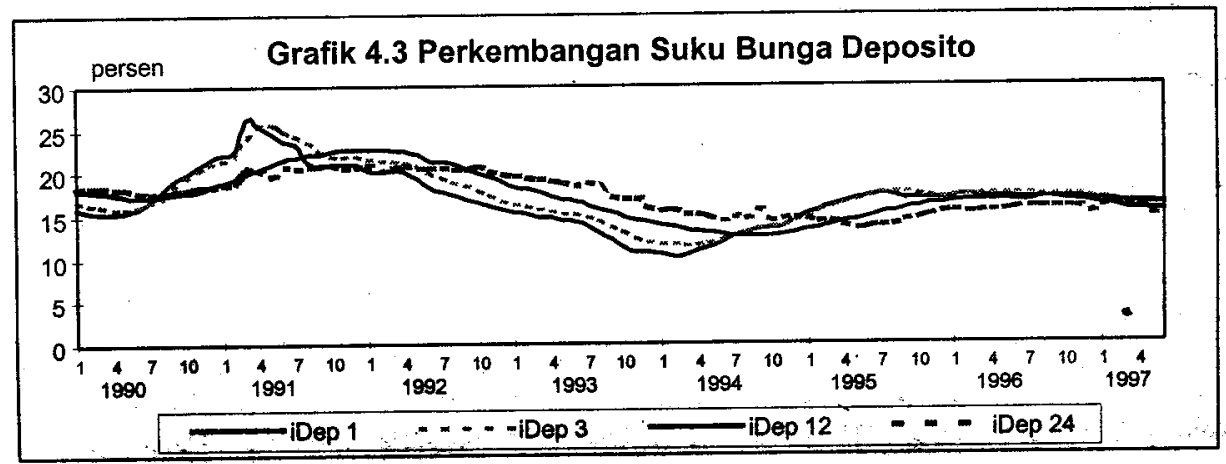




\section{A. Analisis Harga Di Pasar Modal Dan Perbankan}

Berdasarkan analisis harga dengan uji statistik terhadap rata-rata selisih pertumbuhan indeks harga saham (sebagai indikator pendapatan di pasar modal) menunjukkan adanya rata-rata selisih positif antara pendapatan di perbankan dengan pasar modal terhadap suku bunga deposito untuk tiap jangka waktu penanaman. Kondisi ini menunjukkan bahwa pada periode dimana likuiditas longgar (Pakmei '93) serta pasar modal sudah mulai berkembang, pertumbuhan IHSG lebih besar dari suku bunga deposito, sehingga penanaman dana di pasar modal lebih menarik baik dari segi likuiduitas maupun pendapatan yang diterima.

Sementara itu pada periode 1995-97, terlihat rata-rata selisih mengecil bahkan menunjukkan angka yang negatif berkisar antara $-0,78 \mathrm{~s} . \mathrm{d}-0,46$. Bagi penanaman berjangka waktu 1 bulan, selisih tersebut semakin mengecil mendekati nol namun masih positif yang berarti untuk segmen ini pasar kian terintegrasi, sehingga terjadi substitusi yang tidak terlalu kuat antara penanaman di pasar modal dengan deposito 1 bulan. Sedangkan untuk penanaman dengan jangka waktu lebih panjang terdapat selisih negatif, namun kecil mendekati nol sehingga dapat diartikan bahwa pasar tidak bersaing secara sempurna.

Berdasarkan analisis di atas dapat disimpulkan bahwa selisih pendapatan di kedua pasar dari waktu ke waktu cenderung mengecil mendekati nol terutama pada periode 1995-97, yang berarti bahwa pasar semakin terintegrasi sehingga memungkinkan terjadinya perpindahan dana dari perbankan ke pasar modal atau sebaliknya. Namun apabila unsur dividen yang berkisar 1-2\% dari nilai nominal saham (data tahun 1996) diperhitungkan, maka nilai yang negatif akan menjadi positif namun kecil, sehingga dapat dikatakan bahwa disintermediasi masih terjadi walaupun tidak terlalu kuat.

\section{B. Uji Korelasi Harga Dan Kausalitas Granger Antara Harga Di Pasar Modal (Ihsg)} Dengan Perbankan (Suku Bunga)

Hasil uji keterkaitan (korelasi) antara IHSG untuk jangka waktu 12 atau 24 bulan dengan suku bunga deposito pada peroide 1990-97 menunjukkan adanya korelasi negatif berkisar $-0,65$ s.d -0,8 (lampiran 1 angka Ib), yang berarti terdapat substitusi pada penanaman atau permintaan dana jangka panjang sedangkan untuk jangka pendek tidak terdapat hubungan substitusi.

Identik dengan hasil tes korelasi, hasil tes Granger menunjukkan bahwa pada periode 1990-97 suku bunga deposito 12 bulan mempengaruhi pertumbuhan IHSG, namun sebaliknya untuk jangka waktu 24 bulan suku bunga deposito yang mempengaruhi IHSG yang dapat diartikan bahwa pada segmen ini pasar modal terintegrasi dengan perbankan. Sementara itu, pada periode awal pertumbuhan pasar modal (1990-93) suku bunga deposito 3 bulan lebih berpengaruh terhadap pertumbuhan IHSG, sementara untuk periode 199397 deposito 12 bulan lebih berpengaruh terhadap pertumbuhan IHSG. Dapat dikatakan bahwa telah terjadi pergeseran pola pertumbuhan IHSG, yang semula identik dengan penanaman dana dalam jangka pendek menjadi agak panjang serta pergeseran motif dari motif spekulasi menjadi motif investasi akibat perubahan persepsi pelaku pasar. 


\section{Pengujian Terhadap Kuantitas di Pasar Modal dan Perbankan}

Dengan memperhatikan besaran nominal ditemukan korelasi yang kuat antara kapitalisasi pasar dengan deposito dan antara kapitalisasi pasar dengan kredit (koefisien korelasi sebesar 0,98 ). Korelasi yang'kuat tersebut terjadi untuk keseluruhan periode pengamatan maupun untuk masing-masing penggal waktu. Korelasi yang ditemukan tersebut menunjukkan bahwa secara nominal, pasar modal merupakan komplemen kuat dari perbankan baik bagi pihak yang mempunyai dana maupun pihak yang membutuhkan dana.

Sementara itu, hasil uji kausalitas Granger untuk seluruh periode menunjukkan adanya hubungan timbal balik (saling mempengaruhi) antara deposito dengan kapitalisasi pasar, khususnya untuk periode 1993-94 dan 1995-97 ditemukan pengaruh kausalitas yang kuat dari deposito terhadap kapitalisasi pasar. Sebaliknya, jumlah dan perubahan kredit perbankan dalam periode 1990-97 mempunyai hubungan kausalitas dua arah dengan kapitalisasi pasar. Dengan demikian dari segi jumlah terdapat hubungan saling mempengaruhi antara kuantitas deposito dengan kapitalisasi pasar di pasar modal untuk seluruh periode pengamatan (1990-97).

\section{Hubungan Disintermediasi dengan Efektivitas Kebijakan Moneter}

Pertumbuhan M2 jika diamati secara grafis memperlihatkan kecenderungan meningkat dengan fluktuasi yang semakin mengecil (Grafik 4.4), hal ini dapat diartikan bahwa secara umum kebijakan moneter semakin efektif. Namun hasil uji statistik atas M2 selama beberapa periode memperlihatkan nilai rata-rata dan standar deviasi perubahan M2 menurun sampai pertengahan 1993, dan kemudian meningkat sampai pertengahan 1997. Sementara berdasarkan hasil uji Statistik terhadap residual yang diperoleh dari perubahan M2 yang dimodifikasi dengan perkiraan model "best fitted ARMA" (ARMA1, 2 atau kombinasi keduanya) memperlihatkan nilai rata-rata dan standar deviasi untuk masing-masing penggal waktu pengamatan yang semakin mengecil sejak tahun 1990 sampai akhir 1994. Pada periode (1995-1997) standar deviasi untuk residual perubahan M2 (dM2) meningkat kembali namun tidak untuk residual pertumbuhan M2 (gM2). Dengan demikian, secara umum kebijakan moneter efektif meskipun menjadi kurang efektif pada periode 1995-97.

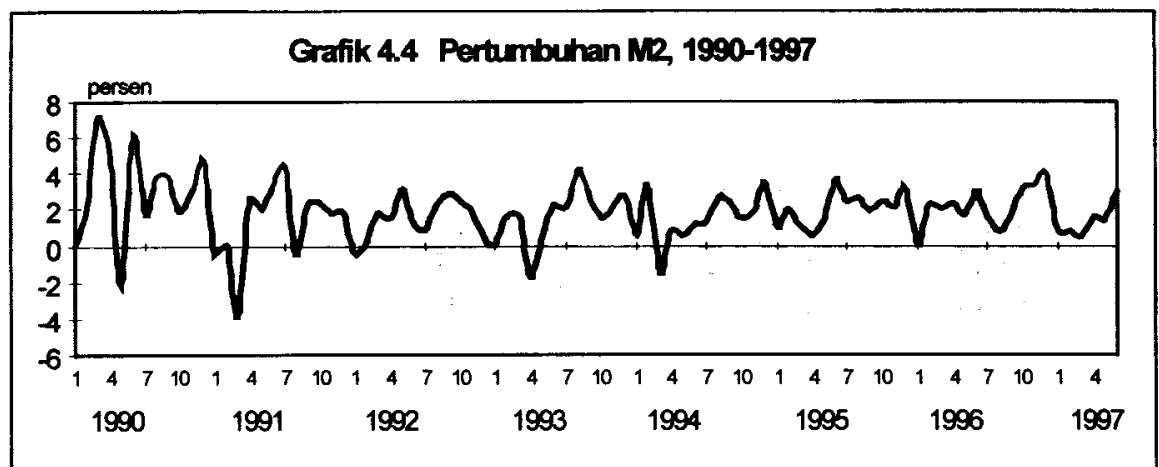


Sejauh ini kebijakan moneter yang diambil oleh Bank Indonesia hanya dapat mempengaruhi secara langsung pada sektor perbankan, dengan demikian sejauh mana pengaruh disintermediasi terhadap efektivitas kebijakan moneter merupakan salah satu aspek yang perlu dikaji. Dengan melakukan uji korelasi ditemukan bahwa tidak ada hubungan antara selisih pendapatan dalam penanaman dana dengan pertumbuhan uang beredar. Korelasi ditemukan antara pertumbuhan M2 dengan selisih suku bunga deposito, dan antara pertumbuhan M2 dengan pertumbuhan IHSG dalam periode 1990-97 menunjukkan angka positif yang kecil berkisar antara 0,08 s.d 0,16 dan secara statistik tidak signifikan. Sementara itu nilai korelasi rata-rata yang cukup besar terjadi pada periode 1991-93 dan 1993-94 (sekitar 0,2 s.d 0,4) walaupun tetap tidak signifikan. Dalam periode pengamatan terakhir (1995-97) terlihat korelasi yang semakin mengecil, yang menunjukkan bahwa hampir tidak ada hubungan antara pertumbuhan M2 dengan perbedaan pendapatan yang diharapkan melalui penanaman di bank atau pasar modal

Lemahnya dampak disintermediasi terhadap efektivitas kebijakan moneter berdasarkan uji korelasi tersebut didukung oleh kecilnya pengaruh pertumbuhan kapitalisasi saham terhadap pertumbuhan uang beredar serta kecilnya hasil tes korelasi antara pertumbuhan M2 dengan pertumbuhan kapitalisasi pasar yang berkisar antara 0,1 s.d 0,15, namun sebaliknya korelasi antara pertumbuhan M2 dengan pertumbuhan kredit relatif besar yaitu berkisar antara 0,3 dan 0,6. Rata-rata korelasi tersebut bernilai positif kecuali pada masa kebijakan uang ketat (1991-93) dimana pertumbuhan M2 agak berkurang namun kredit dan pasar saham masih meningkat. Hal ini terjadi karena kondisi uang ketat memerlukan selang waktu tertentu untuk dapat mempengaruhi nilai kapitalisasi pasar.

Sementara itu, antara M2 dengan kredit maupun kapitalisasi pasar pada keseluruhan periode tidak saling mempengaruhi, baik untuk keseluruhan periode maupun untuk masing-masing penggal waktu. Uji kausalitas Granger untuk M2 dengan pertumbuhan kredit memperlihatkan bahwa pada pada periode likuiditas ketat (1991-93) M2 dan pasar dana tidak saling mempengaruhi, sementara itu pada periode likuiditas longgar (1990-91) dan (1993-94), M2 mempengaruhi pertumbuhan kredit secara signifikan sebesar $99 \%$. Pada periode akhir pengamatan (1995-97) kredit dan M2 juga tidak saling mempengaruhi. Dengan demikian, hipotesa bahwa kebijakan moneter yang tercermin dalam perubahan/ pertumbuhan uang beredar dipengaruhi oleh pertumbuhan kredit tidak selalu terpenuhi.

Berangkat dari asumsi bahwa bahwa kebijakan moneter yang efektif antara lain akan terlihat dari kecilnya gejolak yang tidakdiharapkan (unexpected shock) dalam perubahan M2 yang tidak bisa dijelaskan, pengujian dengan metode regresi ARMA menunjukkan bahwa untuk keseluruhan periode pengamatan (1990-97) perubahan kredit maupun perubahan kapitalisasi saham sedikit berpengaruh terhadap residual perubahan M2. Sementara berdasarkan analisis regresi menggunakan $A R(1)-M A(2)$ diperoleh koefisien regresi untuk kredit sebesar 0,16 dan untuk kapitalisasi pasar sebesar 0,04 dengan nilai $R^{2}$ sebesar 0,11. Hasil tersebut menunjukkan bahwa perubahan kredit dan perubahan kapitalisasi saham secara bersama-sama hanya berpengaruh sebesar 11\% terhadap residual M2.

Koefisien regresi yang kecil tersebut menggambarkan juga bahwa gejolak (shock) dalam M2 hanya sebagian kecil yang dapat dijelaskan oleh perubahan kredit. Hal ini mengindikasikan bahwa pada periode 1990-97, faktor-faktor diluar perubahan kredit dan kapitalisasi pasar lebih berpengaruh terhadap residual M2. Sementara itu berdasarkan pengamatan secara penggal waktu, hanya pada periode 1993-94 diperoleh hasil regresi 


\section{Buletin Ekonomi Moneter dan Perbankan, Juli 1998}

antara residual M2 dengan pertumbuhan kredit dan uang kartal yang signifikan dengan koefisien 0,5 dan 0,2 .

Sejalan dengan hasil uji regresi tersebut, uji korelasi menunjukkan relatif kecilnya korelasi antara perubahan kredit dan perubahan kapitalisasi pasar terhadap residual M2, dimana untuk keseluruhan periode pengamatan (1990-97) masing-masing berkisar antara 0,28-0,33 dan 0,09-0,23. Sedangkan pada periode 1991-93 rata-rata koefisien korelasi tersebut terlihat paling signifikan dibandingkan dengan periode lainnya, sementara periode 1995-97 koefisien korelasi kapitalisasi pasar lebih besar daripada koefisien korelasi perubahan kredit.

\section{Proses Disintermediasi Kegiatan Bank di Beberapa Negara Lain}

Proses disintermediasi kegiatan bank telah terjadi di beberapa negara, diantaranya adalah: Spanyol, Perancis dan Korea Selatan. Disintermediasi di negara-negara tersebut terutama dipicu oleh perkembangan pasar modal serta lembaga keuangan non-bank lainnya. Untuk mengetahui bagaimana proses disintermediasi yang terjadi serta dampaknya terhadap efektivitas kebijakan moneter di masing-masing negara tersebut dapat diuraikan sebagai berikut :

\section{A. Proses Disintermediasi di Spanyol}

Disintermediasi di Spanyol diawali dengan perkembangan bursa saham Spanyol (Spanish stock exchange) pada tahun 1995 dan 1996 Perkembangan tersebut ditandai dengan peningkatan indeks Ibex 35 yang dipengaruhi oleh menurunnya suku bunga jangka panjang, meningkatnya permintaan saham oleh investor domestik khususnya bank dan reksa dana, membaiknya iklim keuangàn internasional khususnya Eropa dan AS, dan terpeliharanya laba perusahaan yang cukup tinggi. Selama periode 1994-1996 penerbitan surat berharga yang dapat diperdagangkan (marketable securities) mengalami peningkatan dari PTA 3,46 triliun (1994) menjadi PTA 5,48 (1996). Peningkatan marketable securities tersebut didominasi oleh surat-surat berharga pemerintah yang menunjukkan peran surat berharga pemerintah yang cukup besar sehingga sering digunakan oleh pemerintah Spanyol untuk mempengaruhi tingkat suku bunga pasar uang dan perbankan.

\section{Tabel 5.1. Penanaman Dana Reksa Dana di Spanyol}

(PTA miliar)

\begin{tabular}{lrrrrrr} 
Jenis Penanaman/Assets & 1992 & 1993 & 1994 & 1995 & 1996 & $1997^{*}$ \\
\hline Currency \& Deposits & 151.2 & 350.3 & 403.4 & 611.2 & 802.3 & 985.6 \\
Repo Purchases & $2,422.8$ & $3,644.4$ & $4,060.1$ & $6,401.8$ & $7,694.6$ & $8,049.0$ \\
Securities Portfolio & $3,391.2$ & $5,800.4$ & $6,531.1$ & $4,752.7$ & $9,457.6$ & $11,748.3$ \\
Other assets & 334.7 & 425.2 & 280.5 & 364.0 & 501.7 & 465.7 \\
T o t a I & $6,300.0$ & $10,220.0$ & $11,275.2$ & $12,129.8$ & $18,456.1$ & $21,248.6$ \\
Net Asset Value & $6,280.4$ & $10,294.6$ & $11,249.6$ & $12,193.1$ & $18,708.4$ & $21,427.5$
\end{tabular}


Sejalan dengan perkembangan pasar modal tersebut, reksa dana di Spanyol juga mengalami perkembangan yang semakin meningkat, ditandai dengan meningkatnya nilai total penanaman dana pada berbagai jenis serta nilai aktiva bersihnya (Tabel 5.1).

Proses disintermediasi terlihat dari peningkatan proporsi penanaman dana di reksa dana dibandingkan dengan nilai kredit yang diberikan oleh perbankan dan lembaga perkreditan (Tabel 5.2). Disintermediasi yanng terjadi tersebut tidak menyebabkan terganggunya kegiatan usaha di sektor perbankan dan lembaga perkreditan serta tidak berdampak terhadap efektivitas kebijakan moneter, karena dalam mencapai sasaran kebijakan moneter Banco de Espana lebih banyak menggunakan obligasi pemerintah sehingga target tersebut selalu dapat dicapai, serta luasnya cakupan pemantauan likuiditas perekonomian yang telah meliputi M3 dan ALP.

Tabel 5.2. Kredit Domestik di Spanyol

(dlm PTA miliar)

Jenis Lembaga

Banks

Saving Banks

Credit Co-operatives

Official Credit Institution

Others

Tot a 1
1995

$30,929.0$

$19,487.0$

$1,954.0$

782.0

$3,270.0$

$56,422.0$
1996

$33,150.0$

$21,784.0$

$2,294.0$

747.0

$3,208.0$

$61,183.0$
1997*

$34,616.0$

$23,627.0$

$2,504.0$

743.0

$3,224.0$

$64,714.0$

Sumber : Banco de Espana, Economic Bulletin July 1997

* sampai akhir Juni

\section{B. Proses Disintermediasi di Perancis}

Sedikit berbeda dengan Spanyol, proses disintermediasi di Perancis ditandai dengan banyaknya penerbitan surat-surat berharga seperti CP dan MTN oleh perusahaanperusahaan swasta dan BUMN. Puncak terjadinya proses disintermediasi di Perancis terjadi pada tahun 1987 dimana nilai penerbitan surat-surat berharga mencapai sekitar FRF 500 miliar sedangkan total kredit perbankan pada periode yang sama mencapai sekitar FRF 2000 miliar (Tabel 5.3 dan 5.4). Perkembangan ini menunjukkan bahwa pasar surat-surat berharga di Perancis telah sangat maju sehingga kebutuhan pembiayaan sektor usaha sebagian dapat dipenuhi melalui penerbitan surat-surat berharga. 
Tabel 5.3. Outstanding Penerbitan Surat-Surat Berharga di Perancis Periode 1995-1997

(dlm FRF miliar)

\begin{tabular}{lrrr}
\hline Keterangan & 1995 & 1996 & $1997^{\star}$ \\
\hline Negotiable Debt Securities : & $2,446.4$ & $2,455.2$ & $2,629.7$ \\
CD & 756.9 & 651.2 & 663.1 \\
FIFC Bills & 41.4 & 36.3 & 30.5 \\
CP & 147.4 & 258.9 & 243.5 \\
MTN & 475.5 & 464.2 & 445.2 \\
Treasury Bills & $1,025.2$ & $1,044.6$ & $1,247.4$ \\
Obligasi : & n.a & 670.0 & 459.2 \\
Bond & n.a & 670.0 & 459.2 \\
Total Outstanding SSB & $2,446.4$ & $3,125.2$ & $3,088.9$ \\
\hline
\end{tabular}

Sumber : Banque de France Bulletin Digest, Sept. 1997-No.45

* sampai Juli

FIFC $=$ Financial Companies and Institutions

Peran yang cukup besar dari lembaga keuangan non-bank dalam perekonomian Perancis terlihat dari besar dan relatif stabilnya porsi pembiayaan lembaga keuangan nonbank (OFI) terhadap total berkisar antara $41 \%$ s.d 46\% sejak tahun 1988 (Tabel 5.4). Hal ini menunjukkan bahwa lembaga keuangan non-bank telah sangat berperan dalam perekonomian Perancis.

Tabel 5.4. Outstanding Kredit/Pembiayaan Lembaga Keuangan di Perancis Periode 1988-1997

(FRF miliar)

\begin{tabular}{lrrrrr} 
Tahun & $\begin{array}{r}\text { Banque } \\
\text { de France }\end{array}$ & Banks & $\begin{array}{r}\text { Other Financial } \\
\text { Institution (OFI) }\end{array}$ & Total & $\begin{array}{r}\% \text { OFI } \\
\text { thd Total }\end{array}$ \\
\hline 1988 & 0.1 & $2,545.5$ & $2,201.0$ & $4,746.6$ & 46.4 \\
1989 & 0.1 & $2,988.0$ & $2,355.6$ & $5,343.7$ & 44.1 \\
1990 & 0.2 & $3,438.4$ & $2,493.5$ & $5,932.1$ & 42.0 \\
1991 & 0.2 & $3,660.9$ & $2,625.3$ & $6,286.4$ & 41.8 \\
1992 & 0.1 & $3,802.0$ & $2,715.2$ & $6,517.3$ & 41.7 \\
1993 & 0.2 & $3,681.8$ & $2,778.7$ & $6,460.7$ & 43.0 \\
1994 & 0.2 & $3,604.8$ & $2,768.2$ & $6,373.2$ & 43.4 \\
1995 & 0.2 & $3,621.0$ & $2,895.7$ & $6,516.9$ & 44.4 \\
1996 & 0.3 & $3,595.7$ & $2,760.8$ & $6,356.8$ & 43.4 \\
$1997^{\star}$ & 0.3 & $3,663.6$ & $2,729.0$ & $6,392.9$ & 42.7
\end{tabular}


Seperti juga di Spanyol, pergeseran sumber-sumber pembiayaan dari perbankan ke lembaga keuangan lainnya, tidak terlalu berpengaruh terhadap efektivitas kebijakan moneter, karena dalam pemantauan likuiditas telah digunakan agregat moneter dari M1 sampai M4 dan P1 yang sudah mencakup sumber-sumber penciptaan uang giral di luar perbankan. Di samping itu, banyak lembaga keuangan seperti perusahaan-perusahaan pembiayaan dan manajer investasi berada dalam satu grup dengan bank, sehingga danadana yang dikelola oleh lembaga-lembaga keuangan lain tersebut banyak yang kembali ke bank dalam bentuk giro/deposito dan CD. Sedangkan stabilitas nilai tukar sangat ditunjang oleh kesepakatan EMU (European Monetary Union), hanya mentolerir fluktuasi sekitar $2 \%$ dari kurs tengahnya.

\section{Proses Disintermediasi di Korea Selatan}

Proses disintermediasi di Korea Selatan berlangsung sejak awal tahun 1980-an, ditandai dengan semakin meningkatnya pangsa NBFI's baik dalam penghimpunan dan penyaluran dana masyarakat, hingga mencapai sekitar $30 \%$ dari total kredit/pembiayaan (Tabel 5.5). Salah satu faktor pendorong pesatnya NBFI's tersebut adalah lebih longgarnya ketentuan yang mengatur NBFI's dibandingkan dengan perbankan.

Tabel 5.5. Pangsa Pasar Perbankan dan NBFl's di Korea Selatan

(dalam \%)

Tahun Deposit

Loan

\begin{tabular}{lrrrrr}
\cline { 2 - 3 } \cline { 5 - 5 } & Bank & NBFI's & & Bank & NBFI's \\
1992 & 34.5 & 65.5 & & 45.4 & 54.6 \\
1993 & 31.5 & 68.5 & & 44.3 & 55.7 \\
1994 & 30.0 & 70.0 & & 42.9 & 57.1 \\
1995 & 27.8 & 72.2 & 36.5 & 63.5 \\
1996 & 27.6 & 72.4 & 35.7 & 64.3 \\
$1997^{*}$ & 26.0 & 74.0 & 36.2 & 63.8 \\
\hline
\end{tabular}

Sumber : Bank of Korea

* sampai Agustus

Faktor lain yang mendorong proses disintermediasi di Korea Selatan adalah semakin besarnya peran pasar modal, yang ditunjukkan oleh meningkatnya pertumbuhan kapitalisasi pasar, jumlah emiten di bursa saham, serta besarnya peran investor domestik yang mencapai sekitar $87 \%$ dari total kapitalisasi pasar. Perdagangan di pasar uang dan surat-surat berharga juga telah berkembang pesat (Tabel 5.6), yang sebagian besar berupa corporate bills yang didalamnya termasuk commercial paper. Bila dibandingkan dengan total kredit perbankan, nilai corporate bills pada tahun 1996 ini telah mencapai 45.8\%. Ini menunjukkan bahwa penerbitan surat-surat berharga juga memberikan kontribusi yang cukup berarti bagi terjadinya disintermediasi kegiatan perbankan di Korea Selatan. 
Tabel 5.6. Pasar Uang dan Surat-Surat Berharga di Korea Selatan

(dlm miliar won)

\begin{tabular}{lrrrr}
\hline & 1980 & 1985 & 1990 & 1996 \\
\hline Money Market : & $2,544.7$ & $11,854.4$ & $54,238.2$ & $149,939.3$ \\
MSBs* & 3.2 & 504.1 & $15,240.5$ & $25,030.8$ \\
CDs & - & $1,080.9$ & $6,803.5$ & $31,173.4$ \\
RPs & 129.5 & $2,562.7$ & $3,357.1$ & $7,929.1$ \\
Corporate Bills & $2,083.3$ & $7,283.0$ & $22,686.6$ & $81,198.0$ \\
Call** & 178.7 & 423.7 & $3,650.5$ & $4,608.0$ \\
Treasury Bills & 150.0 & - & $2,500.0$ & - \\
Securities Market : & $5,036.1$ & $19,678.4$ & $92,011.4$ & $381,076.7$ \\
Traded Value of & & & & \\
- Stocks & $1,134.0$ & $3,620.6$ & $53,454.5$ & $142,642.2$ \\
- Bonds*** & $3,902.1$ & $16,057.8$ & $38,556.9$ & $238,434.5$ \\
& $(889.9)$ & $(3,578.1)$ & $(3,410.8)$ & $(1,378.4)$ \\
\hline
\end{tabular}

* Monetary Stabilization Bonds diterbitkan oleh Bank of Korea

** Rata-rata transaksi harian selama Desember

*** Angka dalam kurung mewakili nilai perdagangan pada bursa saham

Perkembangan tersebut tidak berpengaruh terhadap efektivitas kebijakan moneter di Korea karena cukup luasnya cakupan Intermediate Target yang digunakan meliputi M2 dan MCT (penjumlahan dari M2, CD dan money in trust yaitu dana yang ditempatkan oleh bank dalam surat-surat berharga sebagai unit penyertaan semacam mutual fund.

\section{Kesimpulan dan Saran}

\section{Kesimpulan}

1. Meskipun sejauh ini belum ada ukuran yang baku untuk mengukur disintermediasi yang terjadi di sektor keuangan, namun proses tersebut dapat diamati dengan menggunakan pendekatan integrasi di pasar keuangan, dimana dana dapat berpindah dari satu pasar ke pasar yang lain dengan mudah tanpa batasan. Dengan pendekatan tersebut, hasil uji statistik terhadap selisih antara pendapatan di pasar modal dengan perbankan yang semakin mengecil selama periode pengamatan (1990-97) menunjukkan bahwa kedua pasar tersebut terintegrasi, sehingga dapat disimpulkan bahwa telah terjadi disintermediasi kegiatan bank (terutama pada periode pengamatan 1995-97), meskipun secara keseluruhan masih relatif lemah karena pertumbuhan kedua pasar masih searah dan tidak saling meniadakan. Terjadinya proses disintermediasi, khususnya dana jangka panjang, ditunjukkan oleh hubungan antara suku bunga jangka panjang perbankan dengan pendapatan di pasar modal yang bersifat substitusi.

2. Disintermediasi yang sudah terjadi, secara umum tidak berpengaruh terhadap efektivitas kebijakan moneter, karena dari hasil uji korelasi pertumbuhan kredit lebih dominan 
daripada pertumbuhan kapitalisasi pasar terhadap pertumbuhan M2. Selain itu ratarata pertumbuhan M2 dari waktu ke waktu masih stabil dengan standar deviasi dan residual yang semakin mengecil. Namun dengan semakin berkembangnya pasar modal, di masa mendatang kemungkinan dampak disintermediasi dapat mengurangi efektivitas kebijakan moneter. Hal ini terlihat pada hubungan antara perubahan kapitalisasi pasar dengan indikator efektivitas kebijakan moneter selama beberapa periode cenderung semakin erat dibandingkan dengan perubahan kredit.

3. Berdasar pengalaman di beberapa negara lain yang sudah mengalami proses disintermediasi, dapat disimpulkan bahwa : (i) proses disintermediasi yang terjadi tidak terlalu mengganggu kebijakan moneter karena besaran moneter yang dipantau oleh Bank Sentral sudah mencakup kegiatan lembaga keuangan diluar perbankan, (ii) penggunaan suku bunga di pasar uang sebagai target antara (intermediate target) dapat mengendalikan likuiditas perekonomian secara efektif, (iii) suku bunga surat berharga pemerintah dan Bank Sentral dapat dijadikan sebagai acuan (benchmark) dalam penentuan suku bunga baik oleh pasar uang maupun perbankan, dan (iv) luasnya cakupan kewenangan pengawasan Bank Sentral tidak hanya kepada perbankan tetapi juga lembaga pemberi kredit lainnya ternyata sangat mendukung upaya untuk mengantisipasi dampak disintermediasi terhadap efektivitas kebijakan moneter.

\section{Saran}

Untuk menjaga agar kebijakan moneter tetap efektif, dapat dipertimbangkan kemungkinan penggunaan suku bunga sebagai target antara serta dengan memperluas cakupan variabel pemantauan dari M2 menjadi M3 (M2 + dana di lembaga keuangan lainnya). Hal ini karena berdasarkan hasil uji korelasi, ditemukan korelasi yanng cukup signifikan antara suku bunga deposito dengan pertumbuhan Indeks Harga Saham Gabungan (IHSG). 
140 Buletin Ekonomi Moneter dan Perbankan, Juli 1998

\section{Daftar Pustaka}

Bagian Riset Biro Pengelolaan Investasi dan Riset SPPM - Bappepam,"Statistik Pasar Modal", Berbagai edisi.

Banco de Espana,"Economic Bulletin" July 1997.

Bank Indonesia,"Statistik Ekonomi Keuangan Indonesia", beberapa edisi.

Banque de France," Banque de France Bulletin Digest" No. 45, September 1997.

Binhadi,"Financial Sector Deregulation, Banking Development and Monetary Policy - The Indonesian Experience", Institute Bankir Indonesia, Jakarta, 1995.

Foley, Bernard J., “Capital Markets”, Mac. Millan Press Ltd.,1991.

Gujarati, N. Damodar, "Basic Econometrics", 37d edition, McGraw-Hill, 1995.

Jakarta Stock Exchange,"JSX Monthly Statistic", berbagai edisi.

Junghun O.H., "Financial Disintermediation and Monetary Policy", The SEACEN Center, Kuala Lumpur - Malaysia, 1997.

Mishkin FS, The Economics of Money, Banking and Financial Markets, Harper Collins, 1995.

Schwart, G.W and Smith C.W. Jr, "Empirical reslut in Capital Markets", McGraw-Hill, New York, 1992.

Sjahrir," Analisis Bursa Efek", PT. Gramedia Pustaka Utama, Jakarta, 1995.

Solnik, B., "International Investment Reading", $3^{\text {rd }}$ ed., Massachusets Addison Wesley, 1996.

The Bank of Korea," The Bank of Korea Organization and Fuction", August 1997.

The Bank of Korea,"Financial System in Korea", August 1997.

The Bank of Korea,"The Korean Economy", August 1997. 